Carmel, R. \& Herbert, V. (1967) Correctable intestinal defect of vitamin $B_{12}$ absoprtion in pernicious anaemia. Annals of Internal Medicine, 67, 1201.

Cooke, W.T., Fone, D.J., Cox, E.V., Meynell, M.J. \& GADDIE, R. (1963) Acute folic acid deficiency of unknown aetiology: temperate sprue. Gut, 4, 292.

Creamer, B., Shorter, R.G. \& Bamforth, J. (1961) The turnover and shedding of epithelial cells. Gut, $2,110$.

Creamer, B. (1964) Malignancy and the small intestinal mucosa. British Medical Journal, 2, 1435.

DRUMmond, M.B. \& MonTgomery, R.D. (1970) Acute sprue in Britain. British Medical Journal, 2, 340.

Foroozan, P. \& TRIER, J.S. (1967) Mucosa of the small intestine in pernicious anaemia. New England Journal of Medicine, 277, 553.

Forshaw, J. (1968) Faecal fats and the coeliac syndrome. Lancet, 1, 1204.

ForshaW, J. (1969) Effect of vitamin $\mathbf{B}_{12}$ and folic acid deficiency on small intestinal absorption. Journal of Clinical Pathology, 22, 551.

GIRDwOoD, R.H. (1953) A folic acid excretion test in the investigation of intestinal malabsorption. Lancet, ii, 53.
LABLOND, C.P. \& MeISSER, B. (1958) Renewal of chief cells and goblet cells as shown by radioautography after injection of thymidine- $\mathrm{H}^{3}$ into mice. Anatomical Records, 132, 247.

O'Brien, W. \& ENGLAND, M.J.W. (1966). Military tropical sprue from South East Asia. British Medical Journal, 2, 1157.

Phillips, F.S. \& Thiersch, J.B. (1949). Studies of the action of 4-aminopteroylglutamic acid in rats and mice. Journal of Pharmacology, 95, 303.

Reynolds, E.H., Hallpike, J.F., Phillips, B.M. \& MAthews, D.M. (1965) Reversible absorptive defects in anticonvulsant megaloblastic anaemia. Journal of Clinical Pathology, 18, 593.

Shechy, T.W., CoHEN, W.H. \& BrodsKy, J.P. (1963) Intestinal lesions in the initial phase of tropical (military) sprue. American Journal of Digestive Diseases, 8, 826.

STEFANINI, M. (1948) Clinical features and pathogenesis of tropical sprue. Medicine (Baltimore), 27, 379.

TRIER, J.S. (1962) Morphological alterations induced by methotrexate in the mucosa of human proximal intestine. Gastroenterology, 42, 295.

\title{
Active chronic hepatitis and haemolytic anaemia associated with Rh-specific antibodies
}

\author{
C. D. R. Pengelly \\ M.D., F.R.C.P., F.R.C.P.E. \\ Consultant Physician
}

\author{
R. C. JENNINGS \\ M.D., F.R.C.Path. \\ Consultant Pathologist
}

Active chronic hepatitis, a disease also known by the synonyms lupoid hepatitis, plasma cell hepatitis, chronic juvenile hepatitis and by a number of others, is now recognized as a not uncommon condition (Sherlock, 1968). None of these synonyms is entirely satisfactory but the name lupoid hepatitis has been used because in $15 \%$ of patients disturbance of the immunity mechanisms gives rise to a positive LEcell test. Another manifestation of auto-immunity may be the development of a positive Coombs' test, or even a frank haemolytic anaemia (Read, Harrison \& Sherlock, 1963), but this appears to be a rare complication of the disorder and these authors report only one case. We have been unable to find any references to patients with specific antibodies on the red cells or in the serum.

\section{Case history}

Mrs E. F., aged 62 years, without any previous illness of note, was referred to one of us (CDRP) on 22 February 1969. She had become jaundiced about 6 weeks previously. Her stools had been pale and urine dark. The illness had consisted of vague

Requests for reprints to C. D. R. Pengelly, 62 Manchester Road, Altrincham, Cheshire. upper abdominal pain, nausea, heartburn and a little dysphagia referred to the lower end of the oesophagus. There was no history of alcoholism or of the taking of drugs. She had had two normal pregnancies and no miscarriages, and she had never received any blood transfusions or injections of blood. The illness was accepted by her general practitioner as being an example of ordinary viral hepatitis and the jaundice apparently improved, but had become worse a few days before 22 February. Liver function tests had shown the following results: bilirubin $3.6 \mathrm{mg} / 100 \mathrm{ml}$; alkaline phosphatase 34 KA units $/ 100 \mathrm{ml}$; thymol turbidity 6.5 units; SGOT $148 \mathrm{IU} / 1$ at $25^{\circ} \mathrm{C}$; SGPT $168 \mathrm{IU} / 1$ at $25^{\circ} \mathrm{C}$; total protein $8.7 \mathrm{~g} / 100 \mathrm{ml}$; albumin $3.2 \mathrm{~g} / 100 \mathrm{ml}$; globulin $5.5 \mathrm{~g} / 100 \mathrm{ml}$; electrophoresis showed marked increase in gamma-globulin.

On examination she looked generally well and was moderately jaundiced. Her liver was only slightly enlarged but very easily palpable and firm. Urine contained both bile and an excess of urobilinogen but was otherwise normal. There were no clinical signs of liver failure, no spider naevi and no palmar erythema. Her spleen was not palpable. Her blood pressure was $160 / 90 \mathrm{mmHg}$. She was admitted 
to hospital for further investigation on 25 February 1969. On admission there were no new clinical features though after a few days her spleen became just palpable and her liver had enlarged to about $3.5 \mathrm{~cm}$ below the costal margin and was still very firm.

\section{Investigations}

ECG and X-ray chest normal. Serum electrolytes normal; blood urea $23 \mathrm{mg} / 100 \mathrm{ml}$; ESR (Wintrobe) $50 \mathrm{~mm} / \mathrm{hr}$, haemoglobin $11.6 \mathrm{~g} / 100 \mathrm{ml}$, WBC $5700 / \mathrm{mm}^{3}$; differential count; polymorphs $40 \%$, lymphocytes $40 \%$, monocytes $6 \%$, eosinophils $11 \%$ and basophils $3 \%$; reticulocytes $2.4 \%$; blood film; some anisocytosis only; platelets $280,000 / \mathrm{mm}^{3}$; mid-stream urine: no abnormal findings; liver function tests: bilirubin $5.4 \mathrm{mg} / 100 \mathrm{ml}$; alkaline phosphatase $29.5 \mathrm{KA}$ units $/ 100 \mathrm{ml}$ with increase of intestinal isoenzymes suggestive of cirrhosis; thymol turbidity 6.0 units; SGOT $144 \mathrm{IU} / 1$; SGPT 212 $\mathrm{IU} / 1$; protein $7.5 \mathrm{~g} / 100 \mathrm{ml}$, albumin $2.9 \mathrm{~g}$, globulin $4.5 \mathrm{~g}$; immunoelectrophoresis: IgM $100 \mathrm{mg} / 100 \mathrm{ml}$ (normal), IgG $2500 \mathrm{mg} / 100 \mathrm{ml}$ (normal 60-1600), IgA $600 \mathrm{mg} / 100 \mathrm{ml}$ (normal 150-450). Immunofluorescent tests for antinuclear factor (ANF), mitochondrial antibody and smooth muscle antibody all negative; no Australia antigen or antibody detected; thyroid auto-precipitin test, thyrotoxic (anti-microsomal) C-F test and tanned cell agglutinating anti-thyroglobulin titre all negative; prothrombin level $100 \%$; partial thromboplastin time normal; bleeding time (Duke) $2.5 \mathrm{~min}$; serum cholesterol $150 \mathrm{mg} / 100 \mathrm{ml}$; blood group $\mathrm{O}$ Rhesus genotype $R_{2} R_{2}$ (cDE/cDE); occult blood tests on the stools negative or slightly positive; Rose-Waaler test negative; direct Coombs' test positive, serum noted to contain anti-e. Needle biopsy of the liver showed derangement of the normal architecture with a prominent mixed inflammatory cell infiltrate of lymphocytes, plasma cells, eosinophils and some polymorphs both in the portal tracts and in the lobules (Fig. 1). The appearances were those of an active chronic hepatitis with secondary microcirrhotic changes.

Blood from her daughters was tested by the Manchester Blood Transfusion Service and the probable $\mathrm{Rh}$ genotype of both was $\mathrm{R}_{2} \mathrm{r}$ (cDE/cde).

\section{Early treatment and course}

Prednisolone $5 \mathrm{mg}$ b.d. was started on 26 March and she was put on a high protein diet. Within a week she had clinically improved and her liver was less palpable and less firm. Her jaundice was less (bilirubin $4.8 \mathrm{mg} / 100 \mathrm{ml}$ ), but the other liver function tests and immuno-glubulin levels were virtually unchanged. She was discharged on the same dose of prednisolone on 9 April 1969, at which time the

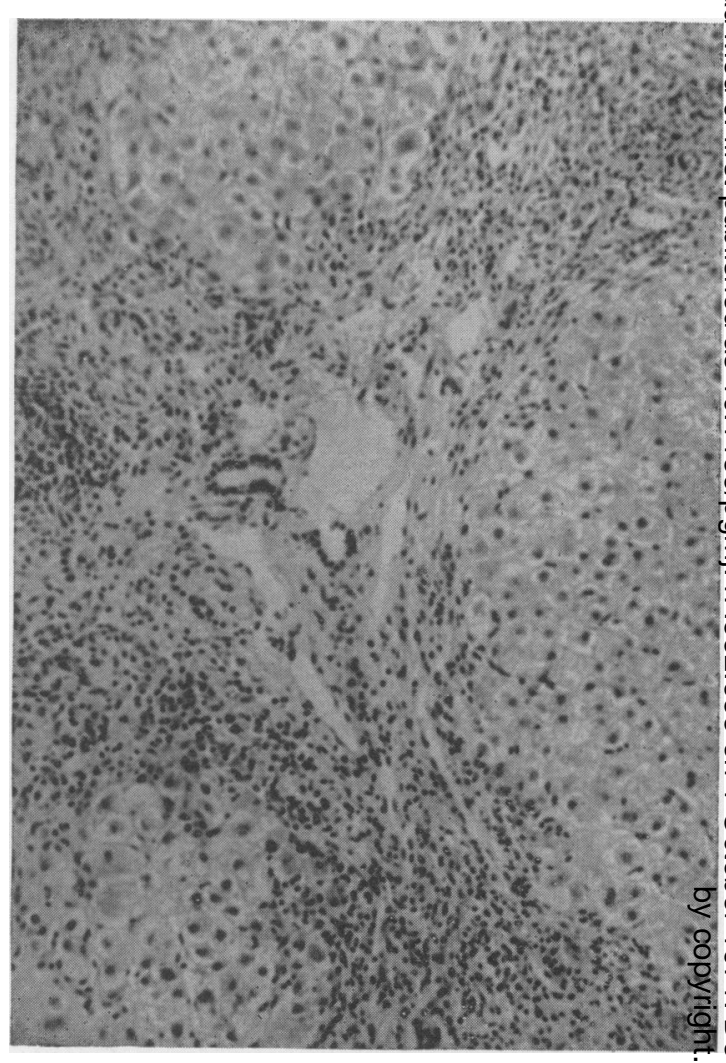

FIG. 1. Needle biopsy of liver, showing a heavy infiltrate of inflammatory cells, both between and within the lobules. H. and E. $\times 160$.

haemoglobin was $10.8 \mathrm{~g} / 100 \mathrm{ml}$, reticulocyte count $3 \%$, and the total white count and differential count were normal.

\section{Haemolytic episode}

She had further improved when seen again in the OPD on $6 \mathrm{May}$, and had gained weight but was still jaundiced and her liver and spleen were still palpable. 3 Hb $8 \cdot 2 \mathrm{~g} / 100 \mathrm{ml}$; WBC $7200 / \mathrm{mm}^{3}$; reticulocytes $10 \%$. Sternal puncture showed an active cellular 3 marrow with normoblastic erythropoiesis, the 0 appearances being compatible with a haemolytic process. Urine contained an excess of both urobilin and urobilinogen, but not bile. Serum haptoglobins showed $125 \mathrm{mg}$ haemoglobin binding $/ 100 \mathrm{ml}$.

She was re-admitted on 22 May with fast auricular N fibrillation. Her haemoglobin was virtually un- N changed at $7.9 \mathrm{~g} / 100 \mathrm{ml}$ but the reticulocytes had $\sigma$ increased to $23.5 \%$. Red cell survival with ${ }^{51} \mathrm{Cr}_{0}$ gave a half chromium time $\left(\mathrm{T}_{1}^{51} \mathrm{Cr}\right)$ of 4.5 days, or a mean cell life span of about 13 days by Method A of Mollison (1956). Serological tests by the Manchester Blood Transfusion Service showed anti-C $\overline{0}$ plus anti-e to be present acting in serum albumin 
at $37^{\circ} \mathrm{C}$ and in the indirect Coombs' test at $37^{\circ} . \mathrm{C}$ but only when cells were washed with saline, cooled to $4^{\circ} \mathrm{C}$ and buffered to $\mathrm{pH} 8 \cdot 2$. The direct Coombs' test was positive, but again only when the cells were washed with saline as above.

Her jaundice persisted (bilirubin $5.8 \mathrm{mg} / 100 \mathrm{ml}$ ) but her other liver function tests showed improvement: alkaline phosphatase $13.5 \mathrm{KA}$ units $/ 100 \mathrm{ml}$; thymol turbidity 1.0 unit; SGOT 34 IU/1; SGPT 11 IU/l; albumin $3.8 \mathrm{~g} / 100 \mathrm{ml}$, globulin $3.1 \mathrm{~g} / 100 \mathrm{ml}$.

\section{Further course and treatment}

The prednisolone dosage was increased to $10 \mathrm{mg}$ t.d.s. on 4 June. She was started on cyclophosphamide $100 \mathrm{mg} /$ day, and her auricular fibrillation controlled with digoxin $0.25 \mathrm{mg}$ b.d. The prednisolone dose was increased to $60 \mathrm{mg}$ daily on $10 \mathrm{June}$. A blood tranfusion of 2 units was given on 13 June 1969. Her haemoglobin gradually rose to 11.6 $\mathrm{g} / 100 \mathrm{ml}$ and it was soon possible to decrease the dosage of prednisolone again (Fig. 2), and the cyclophosphamide was reduced to $50 \mathrm{mg}$ daily on
21 June. She was discharged on 24 July 1969, with a haemoglobin of $11.7 \mathrm{~g} / 100 \mathrm{ml}$, reticulocyte count $3.5 \%$, platelets $200,000 / \mathrm{mm}^{3}$, and $\mathrm{WBC} 2800 / \mathrm{mm}^{3}$. At that time she was taking prednisolone $5 \mathrm{mg}$ b.d. and cyclophosphamide $50 \mathrm{mg}$ daily. She has been reviewed at intervals. Her liver has become much smaller and the spleen impalpable. It has been possible to reduce her steroid therapy to $2 \mathrm{mg}$ of prednisolone daily, but the cyclophosphamide has been continued in the same dose. A further needle biopsy of the liver carried out on 5 March 1970, showed basically the same appearances as before. The liver function tests have been normal since 25 February 1970. Immunoelectrophoresis (June 1969): IgM $100 \mathrm{mg} / \mathrm{ml}$, IgG $1500 \mathrm{mg} / \mathrm{ml}$, IgA 450 $\mathrm{mg} / 100 \mathrm{ml}$. A recent blood count (November 1970) shows haemoglobin $12.9 \mathrm{~g} / 100 \mathrm{ml}$, WBC $4000 / \mathrm{mm}^{3}$, platelets $168,000 / \mathrm{mm}^{3}$.

\section{Discussion}

Doniach et al. (1970) group three liver conditions in their concept of 'autoallergic' hepatitis. These are

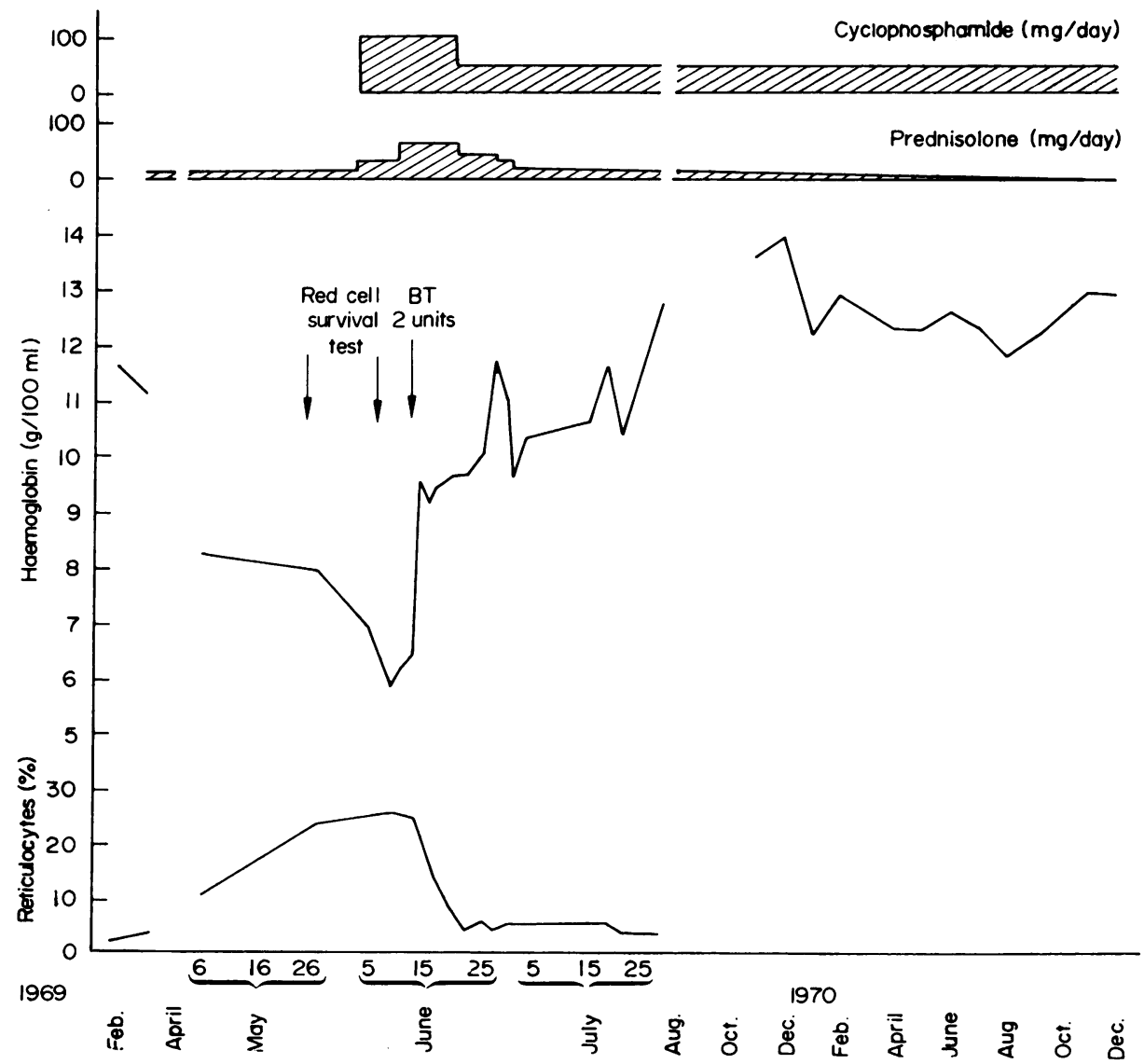

Fig. 2. Showing haemoglobin level, reticulocyte count and therapy. 
biliary cirrhosis, active chronic hepatitis and certain forms of cryptogenic cirrhosis, particularly in women. All these conditions show a high incidence of positive autoimmune marker tests. In our patient although the ANF, mitochondrial and smooth muscle antibody tests were all negative, the LE-cell test was positive and an autoimmune haemolytic anaemia with demonstrable antibodies developed during the course of the active liver disease. The histological changes in the liver on three different occasions showed a picture of a chronic aggressive type of hepatitis with architectural lobular disorganization, the essential features required for a diagnosis of active chronic hepatitis (Scheuer, 1968).

The autoimmune haemolytic anaemia in our patient was associated with antibodies of $\mathrm{Rh}$ specificity (anti-C and anti-e) although her $\mathrm{Rh}$ genotype was $R_{2} R_{2}(c D E / c D E)$. The haemolysis was corrected with adrenocorticosteroid and cyclophosphamide therapy (Fig. 2). We have been unable to find any other comparable case in the literature, although Dacie \& Worlledge (personal communication) have seen one case of chronic hepatitis with haemolytic anaemia and an antibody of $\mathrm{Rh}$ specificity (anti-e).

The inhibitory effect of cyclophosphamide on immunity mechanisms is well known (Tripathy \& Mackaness, 1969a, b; British Medical Journal, 1970). However, in our patient no improvement in the liver lesions was found. The active inflammatory process apparently continued unchanged in spite of the control of the immunological disorder. This is not surprising as the haemolysis is evidence of derangement of immunological balance which is not necessarily related to the underlying pathogenesis of the liver disorder.
The anti-e could have been the result of sensitization during either of her two pregnancies, but the anti-C could not have been accounted for in this way. It seems probable that both antibodies were entirely the result of a deranged immunological mechanism and that they arose at the time of her hepatitis and not before.

\section{Acknowledgments}

We are grateful for the co-operation of Dr F. Stratton of the Regional Blood Transfusion Service for the antibody $\sim$ studies; to Dr P. Scheuer for his confirmatory opinion on the $\vec{\circ}$ liver histology; to Mr D. H. Chetham, F.I.M.L.T. for the photomicrograph (Fig. 1), Mrs V. McKenzie, B.sC., for the $\vec{\omega}$ preparation of Fig. 2, and to Mrs J. White for the typing of the manuscript.

\section{References}

British Medical Journal (1970) Immunosuppressive Drugs-I 4, 663.

DoniaCh, D., WAlker, J.G., RoITt, I.M. \& Berg, P.A. (1970) 'Autoallergic' hepatitis. New England Journal of C Medicine, 282, 86.

Mollison, P.L. (1956) Blood Transfusion in Clinical Medicine, 2nd edn., p. 139. Blackwell Scientific Publications, Oxford.

Read, A.E., Harrison, C.V. \& Sherlock, S. (1963) Juvenile cirrhosis; part of a system disease. The effect of corticosteroid therapy. Gut, 4, 378.

SCHEUER, P.J. (1968) Liver Biopsy Interpretation, Chap. \& Baillière, Tindall \& Cassell, London.

SHERLOCK, S. (1968) Diseases of the Liver and Biliary Systent 4th edn, p. 425. Blackwell Scientific Publications, Oxfor

Tripathy, S.P. \& MACKANESS, C.B. (1969a) The effect of cytotoxic agents on the primary immune response to Listeria monocytogenes. Journal of Experimental Medicine, 130, 1.

Tripathy, S.P. \& Mackaness, C.B. (1969b) The effect of cytotoxic agents on the passive transfer of cell-mediated immunity. Journal of Experimental Medicine, 130, 17. 